\title{
IN PISCIBUS OBSONATORES ET RHETORES: PETR. 39.13*
}

In piscibus (sc. nascuntur) obsonatores et rhetores: thus Trimalchio concludes the signby-sign interpretation he gives in Petr. 39 of the astrological repositorium that has been served some chapters before (35.1-5). While the obsonatores - 'buyers of fish' (TLL 9.234.49-70), from ó $\psi \omega \nu \epsilon \in \omega$, 'buy fish and other dainties' (LSJ s.v.) - pose no problem, ' the rhetores have mystified interpreters since Peter Burman, who frankly confessed: 'Causam non video, cum pisces vulgo muti habeantur, ${ }^{2}$ rhetores vero loquaces. Fortasse corrupta vox. An vectores aut veteratores? Haereo.'

The text is certainly sound. Similar associations of a certain kind of person with a seemingly unrelated or even contrary sign can be found earlier in the catalogue: cf. Petr. 39.10 in uirgine ... fugitiui et compediti and especially 39.11 in sagittario strabones. ${ }^{3}$ Moreover, rhetores corresponds to scholastici in 39.5 (see below), and the structure of the phrase exactly matches 39.11 in scorpione uenenarii et percussores and the immediately preceding in aquario copones et cucurbitae. An interpretative solution is called for.

Many commentators ${ }^{4}$ have tried to solve the riddle by adducing parallels from technical astrological literature. This, however, will not do for several reasons. First, the parallels cited are not exact because they are not valid for the whole of Pisces, but only for particular days, actually the 19th or the 13th to 16th (Firm. Mat. 8.30.7, Vett. Val. 1.3.57), or because the persons born under the sign will not be rhetores, but only prone to (malicious) gossip (Man. 4.573-6, Hippolyt. Haer. 4.26.2, Heph. Astr. 3.9.15, 16.5); the best parallel that has shown up until now, puer natus in signo piscis ... eloquens erit, still speaks of eloquence only in general terms and comes from a fifteenth-century manuscript. ${ }^{5}$ Secondly, the loci similes are matched by loci contrarii that classify the sign itself as mute (Vett. Val. 1.2.78, Firm. Mat. 2.10.5, Heph. Astr. 1.1.216, Teucer ap. Rhetor. in Corp. Cod. Astr. 7.211.4) and predict that people born under it will stammer or speak slowly (Vett. Val. 2.36.19, Heph. Astr. 2.2.39). In addition, ancient astrological treatises provide the reader with such an immense amount of possible professions and characteristics for each sign of the zodiac that the worth of the inexact parallels cited above approximates to zero. But the worst thing is that Trimalchio does not seem to be concerned with scientific astrology at all. As Sven

\footnotetext{
I would like to thank Manuel Baumbach, Gerald Bechtle, Florian Schaffenrath, Stefan Tilg and the anonymous readers for their helpful comments and criticisms.

1 Cf. first de Vreese (1927) 203-7, then e.g. Eriksson (1956) 68; Smith (1975) 91.

Cf. Engemann (1969) 1007-8.

On these passages, see e.g. de Vreese (1927) 39-82; Eriksson (1956) 61-2, 64-5.

De Vreese (1927) 215; Smith (1975) 92; Pellegrino (1975) 281; Grondona (1980) 25 n. 61.

"Cod. Vat. Urb. Lat. 1398 (Svenberg (1963) 99.15-20).
} 
Eriksson has shown, his catalogue in Petr. 39 is a splendid example of popular astrology, ${ }^{6}$ improvised according to the principles of similarity and association and not refraining from allusions to the present situation and to the members of the party. ${ }^{7}$ So one would do better to abandon the technical treatises and rather search for an explanation based on popular ideas about fish and rhetores or capable of providing a link to the actual situation of the Cena.

That is what Jacques de Vreese tries to do when he points to the Platonic idea of rhetoric as a counterpart to the art of cooking, which underlies Encolpius' denigration of contemporary rhetoric in Petr. 1.3-2.1, and to the metaphor in 3.4 that likens the rhetor's catching of disciples to fishing. ${ }^{8} \mathrm{He}$ also points out that the rhetores refer, just like the opening mention of scholastici (39.5), in some way to Agamemnon and his friends, so that the catalogue is framed by allusions to the learned guests, an idea applied more specifically by Eriksson: the scholastici should be related to Encolpius and Ascyltus, the rhetores to Agamemnon. ${ }^{9}$ Whereas this last observation is certainly correct - whether the allusions constitute compliments to the hospites docti, or, as seems more probable, are jokes at their expense,$-{ }^{10}$ the hints at Plato's comparison and at the fishing-metaphor cannot be considered equally useful. As to the first, the idea of rhetoric as cooking cannot be evoked by the combination of Pisces and rhetores in itself. De Vreese seems to think that the obsonatores function as a kind of missing link, but they could only do so on his misguided (see above) assumption that obsonatores can also mean 'cooks'. ${ }^{11}$ The hint at 3.4 looks promising at first sight, since the speaker there is Agamemnon himself, and his fishing-simile is preceded by another one (3.3) that involves the hunt for cenas diuitum by ficti adulatores and announces his own parasitic role in the Cena Trimalchionis. ${ }^{12}$ Nevertheless it turns out to be problematic, too, since the application of the fishing-metaphor to rhetores hunting for disciples seems to be unique in ancient

- Eriksson (1956) 38-84. His dichotomy of popular vs. scientific astrology may be a bit too strict, since the first certainly receives some inspiration from the second, but on the whole his point is well made: cf. the following examples from Petr. 39 that seem to have no parallels whatsoever in any scientific astrological treatise: born under aries: people with caput durum, scholastici, arietilli (39.5); under taurus: qui se ipsi pascunt (6); under gemini: colei (7); under cancer: Trimalchio himself - ideo multis pedibus sto et in mari ef in terra multa possideo (8); under aquarius: copones, cucurbitae (12); under pisces: obsonatores (13).

7 For this last point cf. especially the scholastici (Petr. 39.5. see below); qui se ipsi pascunt (6), a hint 'at the contrast between himself (sc. Trimalchio) and his guests, who are glad to accept dinner at his expense' (Smith (1975) 90; cf. also Pellegrino (1975) 274); Trimalchio himself (8); the cataphagae (9), a hint at the voracity of the guests?; and the mulieres (9), 'mit Rücksicht auf die anwesenden Damen?' (Eriksson (1956) 61, with a general remark on the technique).

* De Vreese (1927) 207-13; cf. later Eriksson (1956) 68-9; Pellegrino (1975) 281; Walsh (1996) 169; Courtney (2001) 89 .

" De Vreese (1927) 213, 227, 244; Eriksson (1956) 56, 58.

10 The scholastici are coupled with people having frontem expudoratum and with arietilli, possibly 'ungrateful persons' (Friedländer (1906) 244); for the rhetores see below. Cf. for both possibilities de Vreese (1927) 232-3; Eriksson (1956) 56, 61; for the second one Courtney (2001) 88-9.

1 Cf. de Vreese (1927) 203-7, 211 .

12 Noted first, it seems, by Walsh (1970) 85. 
literature. ${ }^{13}$ If we ask for a minimum of realism in Petronius' rendering of Trimalchio's speech, we cannot accept that the idea should readily come to Trimalchio's mind, let alone that his guests should understand the resulting allusion. ${ }^{14}$ Can we concede that realism may be temporarily suspended and assume that for a moment Petronius himself speaks in Trimalchio's voice, addressing not the guests, but his own audience, who have read 3.4 and thus can decipher the allusion? Maybe - but he really would give them a hard time. In order to understand the allusion, his readers would have to remember 3.4 at no less (and possibly much more) than two books' distance ${ }^{15}$ and to establish a mental link between it and 39.13 with nothing but the coupling of fish and rhetoric in two apparently different contexts to start from. ${ }^{16}$ That someone should have been able to do so, strains credulity. If an easier explanation can be found, it should be preferred.

In the search for such an explanation it seems profitable to go back to what already struck Burman as the crux of the passage: the idea that eloquent rhetores should be born under the sign of mute fish. Following this approach, a solution can indeed be found that respects the limits of Trimalchio's, his guests' and the readers' intellectual capacities and additionally specifies the above-mentioned reference to the situation of the Cena. In antiquity, it was not rare for a speaker to break down in court or on other occasions through extreme stage fright so that he could no longer deliver his speech. ${ }^{17}$ Accordingly, there existed a standard joke about rhetores ${ }^{18}$ who proved unable to speak - either at the decisive moment or even in general. For example, in Mart. 8.7 an angry client complains to his lawyer: Hoc agere est causas, hoc dicere, Cinna, diserte, I horis, Cinna, decem dicere uerba nouem? I Sed modo clepsydras ingenti uoce petisti | quattuor. O quantum, Cinna, tacere potes! In AP 11.145 a certain Sextus is ridiculed:

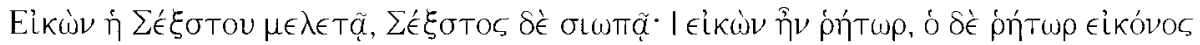
Gikwiv. Ten more epigrams from the Anthologia graeca (AP 11.149, 151, APl. 317-18),

1.3 Fishing is, of course, used as a metaphor for various other human activities: cf. Pöschl et al. (1964) 476-7 s.v. 'Fischfang'. The other two cases where catching fish means catching disciples (Ev. Matt. 4.19 and Ev. Marc. 1.17, D.L. 2.67) have nothing to do with rhetoric. Neither are they connected with each other nor to the present instance: each of them is prompted by its own very specific context (Schmid (1955) 446-7).

14 A similar objection could already have been raised against Trimalchio's alleged Platonic inspiration: Plato is surely beyond his and his audience's intellectual horizon.

15 According to the convincing reconstruction of Harrison (1998) 583-4, the first book of the Cena originally consisted of Petr. 26.7-46.8. Harrison furthermore claims an average length of about 20 Teubner pages for the single books of the original Satyricon (583). 3.4 is at a distance of 18 pages from 26.7 in Müller (2003), but since the text of 3.4-26.7 contains many long lacunce, the original distance must have been much more than 20 Teubner pages - how much more, there is no way to tell. On the whole problem of the Satyricon's book-division see Müller (2003) XXI-III.

16 Petr. 39.13 contains no verbal echo of 3.4 .

17 Korenjak (2000) 108-14; see especially the examples listed at 108 n. 38.

is Rhetor / pritup can mean 'teacher of rhetoric' as well as 'public speaker', the first notion being predominant in Latin, the latter in Greek (OLD s.v. a, b; $L S J$ s.v. 1, 4). The joke is made indiscriminately about members of both groups. Of the examples cited below, Martial speaks about lawyers. Ausonius about a teacher; the ṕf́торєs of the epigrams from the Anthologia graeci remain unspecitied. 
Martial (8.17) and Ausonius (Ep. 45-7, 51-2 Green) can be cited as further evidence for the topos. To be sure, these texts do not compare a mute rhetor to a fish, but the idea is nonetheless close at hand. In Luc. Pisc. 51 another kind of intellectual, namely a stupid philosopher, is styled as a mute fish. In Artem. 2.14 a sophist's dreaming of big fish predicts professional failure, because fish are mute. And the Akathistos hymn

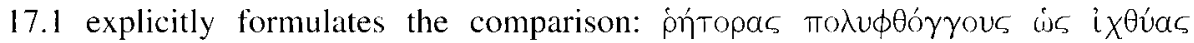

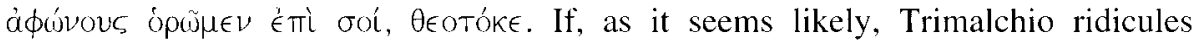
Agamemnon and his profession along these lines, this would produce an exact parallel to his immediately preceding remark in aquario copones (Petr. 39.12), which pokes fun at the proverbial propensity of innkeepers to dilute their wine with water: 19 in both cases, a profession would be satirised by presupposing that its representatives do the opposite of what they are supposed to do. More important, Trimalchio would deftly criticise the actual conduct of Agamemnon, who has not uttered a single word since the beginning of the Cena, ${ }^{20}$ displaying a behaviour judged rude and offensive in antiquity. ${ }^{21}$ In fact, he will be censured openly for that very reason some paragraphs later (but probably still in the same book) ${ }^{22}$ by Echion: ... tu, qui potes loquere, non loquis ... pauperorum nerba derides (46.1)!

INSTITUT FÜR KLASSISCHE PHILOLOGIE DER UNIVERSITÄT BERN

MARTIN KORENJAK

14 Cf: Burman (1743) ad loc,; de Vreese (1927) 182-3; Smith (1975) 91; Pellegrino (1975) 279-80. Probably Trimalchio also wants to highlight his own generous distribution of wine among the guests (Petr. 39.2, 52.7). As with the mute rhetores, the topos is often found in epigrams, especially in Martial: cf. Mart. 1.56, 3.57.9.98: CIL 4.3948.

20 This stands out. Since the actual beginning of the Cena at Petr. 31.3 nearly half of the text has been direct speech, and apart from Trimalchio himself $(33.1-2,5 ; 34.1,2,5,7,10 ; 35.6-7 ; 36.5,7 ; 39.1-15)$, four other (groups of) speakers have been named: Encolpius $(31.5,36.7,37.1)$, a tuetus conuiua (33.8), an unspecified group of persons (34.5), and Encolpius" neighbour (36.8;37.2-38.16). Agamemnon's attitude seems especially strange when compared to that of his young and inexperienced friend Encolpius. With one exception (65.5), the old rhetor will also stay quiet during the rest of the Cena. Shey (1971) 83 rightly remarks: "in the Cena, Agamemnon's silence is noteworthy.'

-1 On silence at dinner as uncivil behaviour of. Plut. Lyc. 20.3, Mor. 147f, 218 b, 660b; also Mor. 682a, 694b (obligation to contribute to the conversation). But Agamemnon has his reasons to stay quiet: cf. Petr. 48.4-8 (Trimalchio asks him to narrate what he has declaimed today, but interrupts the answer with one of his witticisms); $50.2-4$ (addresses him but does not even bother to wait for an answer); 52.7 (Agamemnon knows his acclamations - and not his words - will secure another invitation).

$\therefore$ See above, n. 15. 


\section{BIBLIOGRAPHY}

Burman, P. (1743) T. Petronii Arbitri Satyricon quae supersunt cum doctorsm virorum commentariis (2nd. ed.), Amsterdam.

Courtney, E. (2001) A companion to Petronius, Oxford.

de Vreese, J. (1927) Petron 39 und die Astrologie, Amsterdam.

Engemann, J. (1969) 'Fisch, Fischer, Fischfang', RAC 7, 959-1097.

Eriksson, S. (1956) Wochentagsgötter, Mond und Tierkreis. Laienastrologie in der römischen Kaiserzeit. Stockholm.

Friedländer, P. (1906) Petronii Cena Trimalchionis (2nd. ed.), Leipzig.

Grondona, M. (1980) La religione e la superstizione nella Cena Trimalchionis, Brussels.

Harrison, S. J. (1998) 'Dividing the dinner: book divisions in Petronius' Cena Trimalchionis', CQ 48, 580-5.

Korenjak, M. (2000) Publikum und Redner. Ihre Interaktion in der sophistischen Rhetorik der Kaiserzeit. Munich.

Müller, K. (2003) Petronii Arbitri Satyricon reliquiae. Editio iterata correctior editionis quartae $(M C M X C V)$, Munich and Leipzig.

Pellegrino, C. (1975) Petronii Arbitri Satyricon, Rome.

Pöschl., V. et al. (1964) Bibliographie zur antiken Bildersprache, Heidelberg.

Schmid, W. (1955) 'Die Netze des Seelenfängers. Zur Jagdmetaphorik im philosophischen Protreptikos des Demetrius Lacon (Pap. Herc. 831)', PP 10, 440-7

Shey, H. J. (1971) 'Petronius and Plato's Gorgias', CB 47, 81-4.

Smith, M. S. (1975) Petronii Arbitri Cena Trimalchionis, Oxford.

Svenberg, E. (1963) Lunaria et zodiologia latina, Göteborg.

Walsh, P. G. (1970) The Roman novel, Cambridge.

(1996) Petronius, The Satyricon, Oxford. 